\title{
STATE AUDIT FOR STRENGTHENING THE ACCOUNTABILITY IN PUBLIC FUNDS MANAGEMENT: CASE OF REPUBLIC OF MACEDONIA
}

\author{
Jadranka MRSIK ${ }^{1}$, Tome NENOVSKI ${ }^{2}$, Sanja RADENKOVIC ${ }^{3}$
}

DOI: 10.1515/tjeb-2016-0006

\begin{abstract}
The aim of this paper is to analyze the role of the state audit in strengthening the accountability in managing the public funds. Appropriate and effective use of public funds ensures a healthy economic and financial management, as well as transparency, which leads towards a positive development of the society as a whole. We evaluated the operation of the state audit in Macedonia by analyzing the regularity audit performed on five state institutions from 2010 to 2014 and we compared the results with the state audits in two neighboring countries. Our findings suggest weaknesses in the use of public money by the institutions covered by this analysis and in the operation of the State Audit Office. The research will help in increasing the public awareness about the necessity of responsible management in the public sector.
\end{abstract}

\section{Keywords: $\quad$ State audit, Public funds management, Supreme audit institution, Accountability, Republic of Macedonia}

JEL Classification: M420, M480

\footnotetext{
${ }^{1}$ Associate Professor PhD, University American College, Skopje, Republic of Macedonia.

2 Professor PhD, University American College, Skopje, Republic of Macedonia.

${ }^{3}$ MSc, Stopanska banka Ad Skopje Skopje, Republic of Macedonia.
} 
Mrsik, J., Nenovski, T. \& Radenkovic, S. (2016).

State audit for strengthening the accountability in public funds management: Case of Republic of Macedonia

\section{Introduction}

Public funds are necessary for the operation and execution of processes which are executed by the responsible people in the state institutions. Since public funds are limited, and the costs required to achieve certain goals are constantly increasing the effectiveness of public expenditure has a direct impact on the successful implementation of economic and social processes within the public sector. Therefore, management and control of public expenditure is important for economic, efficient and effective use of public funds.

Uncontrolled public spending in the public sector is a big problem that must be monitored by a separate control unit which is also known as the state audit. Most of the countries had imposed an obligation for reviewing the results of operations of the state bodies and institutions. For this purpose, they established special audit institutions - Supreme Audit Institutions (SAls) which have a different legal status. The SAls's goal is to prevent misuse of public funds and risk management through three main roles of the audit including: testing, assessment and consultation. They use three types of audits: financial (or attest), compliance and performance (or value-for-money) (WB, 2001) to audit the public sector. In addition, SAI give appropriate recommendations and policy management to the public sector for more effective public spending. Improper use of public funds may adversely affect the structure of the state budget.

The conclusions from the resolution of 21st UN/INTOSAI Symposium (2011) on effective practices of cooperation between supreme audit institutions and citizens to enhance public accountability can be summarized in:

- heed citizens' concerns in their work and communicate this accordingly,

- communicate audits and audit findings to the public, and

- empower citizens to demand the implementation of audit recommendations

The subject of research of this paper is the role that the state audit has for strengthening the accountability of the authorized person in the state bodies' when using and managing public funds in the Republic of Macedonia (Macedonia). We evaluate the state audit role in strengthening the accountability of the government's unit management by reviewing the types of opinions on the annual reports of selected users of budget funds. The results from this research will contribute towards raising awareness of the influence of the State Audit Office for responsible use and management of public funds from the State Budget. The final result of the analysis will help to learn about the state audit influence on the improvement of the operation of the state institutions through the elimination of the irregularities and omissions.

DE GRUYTER OPEN
Timisoara Journal of Economics and Business | ISSN: 2286-0991 | www.tjeb.ro Year 2016 | Volume 9 | Issue 2 | Pages: 81-94 
Mrsik, J., Nenovski, T. \& Radenkovic, S. (2016).

State audit for strengthening the accountability in public funds management: Case of Republic of Macedonia

\section{Literature review}

According to Bobes (2012) the effective use of public funds is necessary for the public finance management and for the efficient decisions done by the competent persons in the public sector. In addition, he stressed that the capacity of the public audit is to prevent and/or remove deficiencies in optimum time. Ramkumar and Krafchik (2005) considered the public auditors as watchdogs of public finances who act as critical links in enforcing the accountability of executive agencies to national and state legislatures, and through them to the general public.

For protecting their public funds, the countries form Supreme Audit Institutions (SAI) which is an important tool in regulating the use of public funds (Nguyen, 2012). SAls role is to check whether public funds are being used efficiently, effectively and economically for the intended purposes and if they are in compliance with the existing rules and regulations (Baimyrzaeva andKose, 2005). Therefore, a reliable and objective reporting is critical for SAls to ensure accountability and transparency in the public management. It also helps to the battle against corruption and waste, and suggests options in which government organisations can operate better. And most of it, by ensuring that money is well spent they can contribute to sustainable national development, reduce fraud and contribute to poverty reduction (OECD, 2011).

According to Khann (2013) with increasing emphasis on value for money audits or performance audits, the role of SAls in enforcing accountability has increased significantly. However, lot much depends upon the law and its implementation under which a SAl acts. Koskun (2015) confirms that the SAls play a critical role in promoting accountability transparency within government. Undoubtedly, this function of SAls will continue; capacity will have to be strengthened in accordance with the widened accountability

Akyel (2013) make a conclusion that effective communications with the parliament, audited entities, media, civil society organisations and the public at large will enhance SAl's effectiveness and make it key in responding challenges for ensuring transparency and accountability of the public financial management.

In the last period, these types of institutions succeeded to develop internal capacity but according to OECD (2011) they still do not function in their full capacity in many countries. They lack level of authority, suitable skills and resources in order to carry out the audits and report the results transparently and without fear. Therefore, in the developing countries there is a need for better structured SAls for improving the public financial management and accountability.

DE GRUYTER OPEN
Timisoara Journal of Economics and Business | ISSN: 2286-0991 | www.tjeb.ro Year 2016 | Volume 9 | Issue 2 | Pages: 81-94 
Mrsik, J., Nenovski, T. \& Radenkovic, S. (2016).

State audit for strengthening the accountability in public funds management: Case of Republic of Macedonia

Midaoui (2011) proposes that developing countries firstly have to develop effective audits of regularity and compliance which is essential for developing a culture of control and accountability within the public institutions. According to him, the development of public auditing and SAI capacity building must go hand in hand in a context that fosters the independence of these institutions.

Mahacek and Vcev (2015) affirm the significance of elimination of irregularities and omissions through implementation of audit recommendations for improving business operations and results.

The IDI Global Survey (2014) results suggest that the institutions which are members of the European Organization of Supreme Audit Institutions (EUROSAI) are among the stronger, better performing SAls European Organization of Supreme Audit Institutions. Pintea and Sorin (2009), in their comparative study on the Supreme Audit Institutions of the countries members of the European Union, made a conclusion remarks for the improvement processes of the institutions' activities in the domain of external public audit and financial control. The neutral approach is one of the major concerns related to SAls in the studied Western Balkan countries (Lazarevic et al 2015) and it is influenced by the necessity to distinct the position from the status of SAls, since these are (relatively) new institutions in the studied World Bank countries.

\section{State audit in Macedonia}

According to the principles of revision of the Declaration of Lima (INTOSAI, 1977), orderly and efficient use of public funds is important for the proper management of public finances and for making effective decisions by competent people in the public sector. In order to achieve this, every country needs to have its own independent supreme audit institution. This institution is known in Macedonia as the State Audit Office (SAO). The first bodies for auditing the Government were established in 1945.

The state audit is a relatively new concept in Macedonia and the State Audit Office (SAO) in this country was established in 1999. The subject of audit, in accordance with the Law for state audit (2010), includes: the budget, budgets of local government, budget funds, public companies, National Bank and legal entities where the state is the dominant shareholder. The State audit reports institutions are submitted to Parliament by the end of the fiscal year and before the adoption of the final account.

In the countries with developed economy (CEA, 2012) the operation of the auditors is controlled by a special organization, and in Macedonia the body that performs such activity is the Ministry of Finance.

DE GRUYTER OPEN
Timisoara Journal of Economics and Business | ISSN: 2286-0991 | www.tjeb.ro Year 2016 | Volume 9 | Issue 2 | Pages: 81-94 
Mrsik, J., Nenovski, T. \& Radenkovic, S. (2016).

State audit for strengthening the accountability in public funds management: Case of Republic of Macedonia

The state audit performs: (i) regularity audit concerning the compliance of the work subject to the laws and regulations, and (ii) performance audit concerning the economic, efficient and effective operation and use of funds.

The State audit office of Macedonia has made efforts to comply with the requirements and standards of the European Union. However, the World Bank (2015) after assessing the public financial management with special emphasis to the external scrutiny and audit has announced several concerns:

- Recent proposals to anchor the SAOs role within the Constitution would bring the country into line with INTOSAI standards.

- Requirements to audit the financial operations and reporting of political parties may affect the perception of the SAO's functional independence.

- Improved transparency and accountability could be achieved by developing the capacity of parliament to examine SAO audit reports.

Lazarevic et al (2015) in the conclusion in their study of the issues related to the public sector performance in three Western Balkan countries, indicate that main challenges for performance audit in Macedonia are: improving the quality of performance audit, introducing mechanisms for monitoring the implementation of the recommendations, and generally raising awareness among the institutions regarding the role of performance audits.

\section{Methodology and data}

The methodology is based on a desk research of the documents from legal acts of the state audit, audit reports and State Audit Office report on operation, the annual programs and annual reports. Descriptive analysis is used for analyzing the SAO regularity audit reports for five years, from 2010 to 2014.

We have analyzed the audit report on five state institutions that are the largest users of budget funds in Macedonia: i) Budget, (ii) the Ministry of Finance, (iii) Foreign Investment Agency, (iv) the Pension and Disability Insurance, and (v) Government. In our research we take in consideration only the regularity audit. Additionally, we have reviewed the reports on the implementation of the given recommendations in the previous audit reports to assess in what degree the institutions realize those recommendations for improving their operations.

Comparative analysis and data from state audits of two neighboring countries Serbia and Croatia is also used, in order to see the functioning of the State Audit Office in comparative context. The reason for selecting those countries is that Croatia is already a European Union member state and together with Macedonia and Serbia they have arisen from the same

\section{DE GRUYTER} OPEN 
Mrsik, J., Nenovski, T. \& Radenkovic, S. (2016).

State audit for strengthening the accountability in public funds management: Case of Republic of Macedonia

country, the former Republic of Yugoslavia. We have compared the structure of the expressed opinion of the three state institutions as an average share of a particular type of audit opinion in the total of audit reports during the examined period.

Beside the descriptive and comparative analysis, we have performed an in-depth interview with an experienced state auditor for more detailed explanation and understanding of the State audit office`operation.

The data for the research are collected from the web sites of Macedonian State Audit Office of Macedonia, State Audit Institution of Serbia and State Audit Office of the Republic of Croatia.

We have evaluated the State Audit Organization of Macedonia by:

- analyzing the operation of the State Audit Organization through review of total reports for performed audit during the examined period. The subject of the analysis is: the number of the performed audit by year, the number of follow-up audits by year, the realization of the planned audits in annual programs,

- analyzing the reports on regularity audit of five largest users of budget funds to detect the most frequent auditors' comments in its,

- comparing the operation, organization and regulation of state audit organizations in Macedonia, Croatia and Serbia and

- analyzing the structure of the total audit reports according to the types of audit' opinion.

\section{Results}

\section{Analysis of the audit reports of State audit office of R. of Macedonia from 2010 to 2014}

\subsection{Number of audits}

The number of performed audits is growing after 2012 and the number of follow-up audits for reviewing the implementation status for recommendations is significantly lower in 2014 compared to 2011 and 2010.

Table 1. Number of SAO audits and follow-up audits from 2010 to 2014

\begin{tabular}{lccccc}
\hline & $\mathbf{2 0 1 0}$ & $\mathbf{2 0 1 1}$ & $\mathbf{2 0 1 2}$ & $\mathbf{2 0 1 3}$ & $\mathbf{2 0 1 4}$ \\
\hline Number of audits & 87 & 77 & 54 & 103 & 103 \\
\hline Number of follow-up audits & 72 & 68 & 51 & 37 & 53 \\
\hline
\end{tabular}

Source: The authors, based on Macedonian SAO reports for 2010, 2011, 2012, 2013 and 2014

DE GRUYTER OPEN
Timisoara Journal of Economics and Business | ISSN: 2286-0991 | www.tjeb.ro Year 2016 | Volume 9 | Issue 2 | Pages: 81-94 
Mrsik, J., Nenovski, T. \& Radenkovic, S. (2016).

State audit for strengthening the accountability in public funds management: Case of Republic of Macedonia

\subsection{Planned and performed audits}

The comparison of the performed audits on the five institutions subject of the analyses and the planned audits in annual plans for the period from 2010 to 2014 shows that Pension and disability insurance fund was not audited in 013 and 2014 despite it is a subject of compulsory annual audit according to the State Audit Law. And the Government was not audited in 2014 even it was planned for audit with the Annual program for 2014.

\subsection{The audit opinions structure}

In the SAO annual reports in the period $2010-2014$ the auditors were expressing opinion on:

- Whether the financial statements are showing the financial position and results of the conducted activities in an objective and truthful manner and

- Whether the displayed financial transactions and information are in accordance with relevant legislation, policies and guidelines.

The dynamic of the structure of individual audit opinions for the revised period is presented in the Table 2. The number of reports with unqualified opinion and reports without expressed opinion has decreased in the examined period while the reports with qualified opinion and with negative opinion has increased.

Table 2. Expressed opinions on the reliability and truthfulness of the financial statements given in the annual reports of SAO of Macedonia (2010 to 2014).

\begin{tabular}{lccccc}
\hline \multicolumn{1}{c}{ Expressed opinions } & $\mathbf{2 0 1 0}$ & $\mathbf{2 0 1 1}$ & $\mathbf{2 0 1 2}$ & $\mathbf{2 0 1 3}$ & $\mathbf{2 0 1 4}$ \\
\hline Unqualified opinion & $44 \%$ & $46 \%$ & $38 \%$ & $29 \%$ & $26 \%$ \\
\hline Qualified opinion & $21 \%$ & $27 \%$ & $25 \%$ & $40 \%$ & $45 \%$ \\
\hline Disclaimer of opinion & $22 \%$ & $14 \%$ & $20 \%$ & $10 \%$ & $7 \%$ \\
\hline Negative opinion & $13 \%$ & $13 \%$ & $17 \%$ & $21 \%$ & $22 \%$ \\
\hline
\end{tabular}

Source: The authors, based on data from the website of the State Audit Office of Macedonia

The structure of the opinions expressed by the auditors about the compliance of the financial transactions and information with legislation, policies and guidelines given in the annual reports from 2010 to 2014 is shown in the table below. The reports with unqualified opinion and with disclaimer of opinion have decreased, and the reports with qualified and negative opinion have increased in 2014 compared to 2010.

Table 3. Expressed opinions on the compliance of financial transactions and information with legislation, policies and guidelines referred to in the annual reports of SAO of Macedonia (2010 to 2014).

\begin{tabular}{lccccc}
\hline Expressed opinions & $\mathbf{2 0 1 0}$ & $\mathbf{2 0 1 1}$ & $\mathbf{2 0 1 2}$ & $\mathbf{2 0 1 3}$ & $\mathbf{2 0 1 4}$ \\
\hline Unqualified opinion & $37 \%$ & $31 \%$ & $28 \%$ & $27 \%$ & $22 \%$ \\
\hline
\end{tabular}

\section{DE GRUYTER OPEN}

Timisoara Journal of Economics and Business | ISSN: 2286-0991 | www.tjeb.ro Year 2016 | Volume 9 | Issue 2 | Pages: 81-94 
Mrsik, J., Nenovski, T. \& Radenkovic, S. (2016).

State audit for strengthening the accountability in public funds management: Case of Republic of Macedonia

\begin{tabular}{lccccc}
\hline \multicolumn{1}{c}{ Expressed opinions } & $\mathbf{2 0 1 0}$ & $\mathbf{2 0 1 1}$ & $\mathbf{2 0 1 2}$ & $\mathbf{2 0 1 3}$ & $\mathbf{2 0 1 4}$ \\
\hline Qualified opinion & $23 \%$ & $33 \%$ & $31 \%$ & $46 \%$ & $39 \%$ \\
\hline Disclaimer of opinion & $7 \%$ & $4 \%$ & $3 \%$ & $1 \%$ & $0 \%$ \\
\hline Negative opinion & $33 \%$ & $32 \%$ & $38 \%$ & $26 \%$ & $39 \%$ \\
\hline
\end{tabular}

Source: The authors, based on data from the website of the State Audit Office

\subsection{Audit recommendations implementation}

The SAO audit reports contain 3803 recommendations made for years 2010 through 2014 and state agencies and other audited organizations implemented 1694 (44\%).

\section{Analysis of audit reports of five selected institutions}

The analysis includes audit reports of five institutions from 2010 to 2014. Subject of analysis are: General Budget, Ministry of Finance, Government of RM, Fund for Pension and Disability Insurance, and Agency for Foreign Investments and Export Promotion. The audit was not performed in each of the years during the examined period, and the reason is that some of the institutions were not part of the planned audits in the annual programs of the State Audit Office (Appendix 1).

Summing up the results of the audited reports give the following findings on the work of five institutions in terms of:

o Deviations - All institutions that are subject to this analysis have deviations in their work. Some are repeated in different institutions.

- Systematization of working places - inadequate number of employees or a lack of staff in places where employment was planned.

- Stuff - placing personnel without professional qualifications for jobs that require special skills and expertise.

- Cooperation with other institutions- lack of cooperation between institutions.

- Software- outdated software solution or no option in the software for entering the appropriate documentation.

- Documentation- improper documentation or lack of evidence.

- Procedures and processes- lack of proper procedure needed or no implementation of the already existing working procedures.

- Internal control- internal inadequate system of control or lack of early warning system.

- Public purchases - no implementation of the procurement procedures

DE GRUYTER OPEN
Timisoara Journal of Economics and Business | ISSN: 2286-0991 | www.tjeb.ro

Year 2016 | Volume 9 | Issue 2 | Pages: 81-94 
Mrsik, J., Nenovski, T. \& Radenkovic, S. (2016).

State audit for strengthening the accountability in public funds management: Case of Republic of Macedonia

- Compliance with legislative acts - non-compliance with laws, regulations and other acts within the institutions.

- Audit opinion - qualified opinion is expressed in $67 \%$ of audit reports on compliance with laws and regulations, as well as the objectivity of the financial reports audited. In $25 \%$ of reports unqualified opinion is expressed, and for $6 \%$ of institution has been expressed a negative opinion.

o Implementation of recommendations - All institutions that are subject to this analysis have taken some measures to implement the recommendations over the five-year period, however, they have been partially implemented during the examined period.

\section{Comparison of the state audit organization of Macedonia, Croatia and Serbia}

\subsection{Similarities and differences in organization and operation}

The similarities among the compared audit organizations are: independence, financing by the budget, preparation on annual programs, they are under control of the national assembly, disclosure of audit reports on their web sites, licensing of the auditors, follow-up of the given recommendations in the audit reports and operation according to the International Audit Standards and INTOSAI standards.

The differences are:

- The provision for Macedonian State audit Office is not provided in the State Constitution Law,

- The Macedonian State audit has not a rule book for operation.

- The State Audit Office of Macedonia does not disclose the realization of its strategic goals in the years,

- The State Audit Office of Macedonia dose not disclose the information about the findings in it audit reports for the media representatives and

- The State Audit Office of Macedonia does not disclose the results of the implementation of the subjections from the previous audit reports.

\subsection{Audit opinions on the objectivity and truthfulness of the financial statements}

A comparison of audit opinions on the objectivity and truthfulness of the financial statements of the Macedonian with the opinions expressed on state audits of Serbia and Croatia is made on an average share of a particular type of audit opinion on the reviewed period and provides the following features:

1. Most of the reports of the Macedonian State Audit Office give an unqualified opinion (33\%) and qualified opinion (33\%), but there is a remarkable number of reports with negative opinions (25\%), and lower number of reports without expressed opinion (9\%).

DE GRUYTER OPEN
Timisoara Journal of Economics and Business | ISSN: 2286-0991 | www.tjeb.ro Year 2016 | Volume 9 | Issue 2 | Pages: 81-94 
Mrsik, J., Nenovski, T. \& Radenkovic, S. (2016).

State audit for strengthening the accountability in public funds management: Case of Republic of Macedonia

2. Most of the reports of the Croatian and Serbian state audit offices are with qualified opinion (78\% and $72 \%$ ), and less reports are with unqualified opinion (21\% ie. $25 \%$ ). But significantly low number of reports is without expressed opinion and negative opinion. The Croatian Audit Institution does not have reports without expressed opinion while the Serbian audit institution has only $3 \%$, and only $1 \%$ of the reports of the Croatian and $0.2 \%$ of the Serbian audit reports are with negative opinion.

Our results are with the findings of Mahacek and Funaric (2013) that since 2007th the percentage of unconditional and unfavorable opinions of the State Audit Office of the Republic of Croatia is significantly reduced, and the percentage of conditional opinions increased. Their conclusion is that in all observed years most frequently expressed is a qualified opinion, which is indicating constantly avoiding of the application and partial application of the legal procedures.

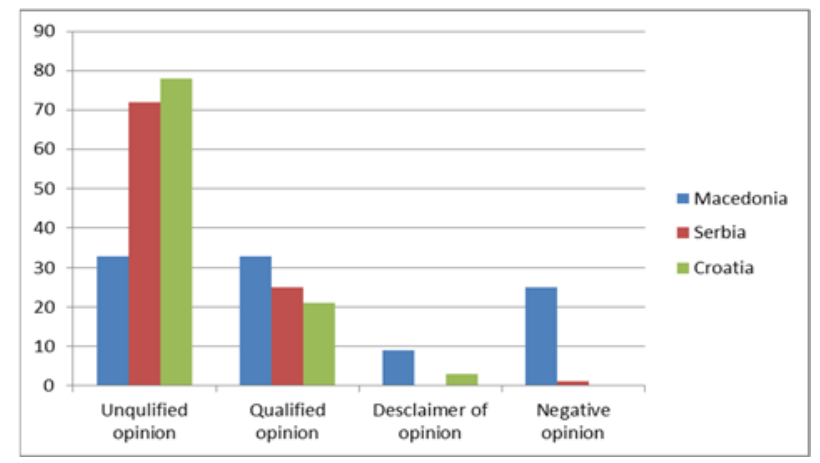

Figure 1. Average opinion structure of the state audit offices of Macedonia, Serbia and Croatia on the objectivity and truthfulness of the financial statements (2010 to 2014) in (\%)

Source: The authors, based on data from the websites of the State Audit Offices of Macedonia, Serbia and Croatia.

\section{Conclusions}

State audit is the leading control mechanism because it helps to improve the work in the public sector by analyzing the performance of those in power. State Audit affects the control of public spending and reduces the risks in the public sector to an acceptable level. SAls are in charge of checking whether public funds are being used for intended purposes efficiently, effectively, and economically in compliance with existing rules and regulations (Ramkumar and Krafchik, 2005).

The results from reviewing the SAO regularity auditing reports for five years (2010-2014) identified several weaknesses in the operation of the examined institutions. Certain observations are repeated in all examined institutions:

DE GRUYTER OPEN
Timisoara Journal of Economics and Business | ISSN: 2286-0991 | www.tjeb.ro Year 2016 | Volume 9 | Issue 2 | Pages: 81-94 
Mrsik, J., Nenovski, T. \& Radenkovic, S. (2016).

- Stuff

- Cooperation with other institutions

- Software

- Documentation

- Procedures and processes

- Public procurement

- Compliance with laws

A comparison of the average structure of the opinions expressed in the audit reports of the Macedonian, Croatian and Serbian state audit institutions from 2010 to 2014, shows that the Macedonian SAO has a higher percentage (33\%) of reports with expressed unqualified opinions, and significantly lower percentage (33\%) of reports with qualified opinion compared to the Croatian and Serbian state audit institutions. However, the data indicating that there is a considerable percentage $(25 \%)$ of reports with negative opinion and a relatively large percentage (9\%) of reports where there is no opinion expressed in comparison to very low percentage of such opinions in the Croatian and the Serbian state audit reports.

We have found several similarities in organization and in operation of the three compared state audit organizations. The similarities are mostly in its: independence, source of financing, planning processes, authorized institution, disclosure of audit reports, process of licensing and of follow-up of the recommendations in the audit reports and compliance with International Audit Standards and INTOSAI standards.

The comparison of functioning of the Macedonian SAO with the SAOs of Croatia and Serbia recognizes a few weaknesses. One is that SAO is not regulated by the Macedonian Constitution Law; the other is the lower transparency in general and in disclosing the realization of the previous recommendations and achieved strategic goals.

The results of this study indicated the need of additional measures and activities to improve the performance to ensure responsible use of public money and to increase the confidence of the citizens. The recommendations are for the policy makers, the SAO and the civil society. Here-in, we present them:

- The regulation of the SAO in the Macedonian Constitution Law,

- To increase the SAO independence,

- To improve SAO transparency by disclosing proper information about the results of the audit to the public,

DE GRUYTER

\section{OPEN}

Timisoara Journal of Economics and Business | ISSN: 2286-0991 | www.tjeb.ro Year 2016 | Volume 9 | Issue 2 | Pages: 81-94 
Mrsik, J., Nenovski, T. \& Radenkovic, S. (2016).

State audit for strengthening the accountability in public funds management: Case of Republic of Macedonia

- To improve the awareness of the state institutions of the role of the state audit and of their responsibility in managing public money,

- To improve public awareness of the importance of the state audit reports for effective management of the public money.

- To establish a public surveillance $n$ the state audit profession,

- To provide effective and real sanction for non-compliance with the law.

- To establish the professional organization for improving the professional capacity of the state auditors.

\section{Appendix}

Appendix 1. Performed audits on the Budget of RM, Ministry of Finance, Government of RM, Pension and Disability Insurance Fund and Agency for Foreign Investments and Export Promotion (2010-2014)

\begin{tabular}{|l|c|c|c|c|c|}
\hline \multicolumn{1}{|c|}{ Institution } & $\mathbf{2 0 1 0}$ & $\mathbf{2 0 1 1}$ & $\mathbf{2 0 1 2}$ & $\mathbf{2 0 1 3}$ & $\mathbf{2 0 1 4}$ \\
\hline Budget of RM & Yes & Yes & Yes & Yes & Yes \\
\hline Ministry of Finance & Yes & No & Yes & No & No \\
\hline Government of RM & No & Yes & No & No & No \\
\hline Pension and Disability Insurance Fund & Yes & Yes & Yes & No & No \\
\hline Agency for foreign investment and export promotion & No & No & Yes & No & No \\
\hline
\end{tabular}

Source: The authors, based on data from the website of the State Audit Office

\section{References}

Akyel, R., (2011). Strengthening Communication Capacity of SAls for Ensuring Good Governance in Public Financial Management, ASOSAI-EUROSAI Joint Conference, Istambul, 2011.

Baimyrzaeva M. and Kose H. O. (2014). The role of supreme audit institutions in improving citizen participation in governance. International Public Management Review Vol. 15, Iss. 2

Bobeş F. M. (2012). Ensuring the legality and performance in using public funds. Romanian Economic and Business Review - Vol. 7, No. 1

Center for Economic Analysis (CEA). (2012). The audit as a profession in the Republic of Macedonia. [online]. Skopje.[05.05.2016] Retrieved from: http://www.cea.org.mk/documents/kolumni/Revizija_u_RM_new.pdf

INTOSAI (International Organization of Supreme Audit Institutions). 1977. "Lima Declaration of Guidelines on Auditing Precepts." Ninth Congress of INTOSAI, Lima, Peru.

DE GRUYTER OPEN
Timisoara Journal of Economics and Business | ISSN: 2286-0991 | www.tjeb.ro Year 2016 | Volume 9 | Issue 2 | Pages: 81-94 
Mrsik, J., Nenovski, T. \& Radenkovic, S. (2016).

INTOSAI Development Initiative (IDI). (2014). Performance, Capacities and Needs of SAls. Global SAI Stocktaking Report. INTOSAI

Khan, Muhammad Akram. (2013). Management Accountability for Public Financial Management.http://siteresources.worldbank.org/PSGLP/Resources/32Accountabili tyforPFMKhan.pdf. November.

Lazarevic et al (2015). Performance audit and policy evaluation in the Western Balkans: On the same or parallel tracks? European Policy Centre

Mahacek D. and Radman Funaric M. (2013). APPLICATION OF STATISTICAL ANALYSIS IN AUDITED COMPANIES OWNED BY LOCAL GOVERNMENTS International Scientific Conference Whither Our Economies" October 24-25, 2013Proceedings, ISSN (online) 2029 - 8501

Mahacek D. and Vcev A. (2015). Statistical Analysis of Companies from Performed Efficiency Audit. Proceedings of MAC-EMM 2015 Multidisciplinary Academic Conference on Economics, Management and Marketing in Prague 2015 / ing. Jiří Vopava ing. Radek Kratochvíl ing. Vladimír Douda (ur.). - Prague : MAC Prague consulting Ltd. , 2015. 66-73 (ISBN: 978-80-88085-00-3).

Midaoui A.E. (2011). Building the professional, organizational and institutional capacity of SAls. International Journal of Government Auditing - April

Nguyen, C.K (2012) Enhancing the effectiveness of budget expenditures by the means of auditing: A case study of State Audit office in Vietnam [online]. Master thesis, Hanoi, University of Tampere.

Organisation for Economic Co-operation and Development (OECD). (2011). Good practices in supporting Supreme audit institutions [online]. Paris.

Pintea M. O. and Sorin A. (2009). Supreme audit institutions, comparative study for the Central and Eastern European countries members of the European Union. The Annals of The "Ştefan cel Mare" University Suceava. Fascicle of The Faculty of Economics and Public Administration. Volume 9, No.1(9)

Ramkumar W. and Krafchik W. (2005). The Role of Civil Society Organizations in Auditing and Public Finance Management.

World Bank (2001). Features and functions of supreme audit institutions. [08.05.2016] Retrieved from: http://www1.worldbank.org/prem/PREMNotes/premnote59.pdf

World Bank. (2015). Report for FYR Macedonia public review: Fiscal policy for growth. Retrieved from: http://respublica.edu.mk/attach/izvestaj.pdf

Laws:

Law on budget (Official Gazette of Republic of Macedonia No.64/0504/08, 103/08, 4/08, 103/08, 156/09, 95/10 156/09, 95/10, 180/11и 171/12).

The Law on State Audit Institution (Official Gazette of RS" No. 101/2005, 54/2007 and $36 / 2010)$

The Law on State Audit Office (Narodne novine 80/11).

Law for State Audit (Official Gazette of Republic of Macedonia" No. 66/10, 145/10, 12/14 and 43/14).

Law on audit (Official Gazette of Republic of Macedonia No.158/10 и 135/11).

Web pages:

National Audit Office of the Republic of Macedonia: http://www.dzr.mk/en.

DE GRUYTER OPEN
Timisoara Journal of Economics and Business | ISSN: 2286-0991 | www.tjeb.ro Year 2016 | Volume 9 | Issue 2 | Pages: 81-94 
Mrsik, J., Nenovski, T. \& Radenkovic, S. (2016). of Economics and Business

State audit for strengthening the accountability in public funds management: Case of Republic of Macedonia

State Audit Institution of Serbia: http://dri.rs/home.4.html

State Audit Institution of Serbia: http://www.revizija.hr

Institute of Certified Auditors of the Republic of Macedonia (http://www.iorrm.org.mk/zanas.h 